\title{
LAWYERS' STRATEGIES FOR CROSS-EXAMINING RAPE COMPLAINANTS: HAVE WE MOVED BEYOND THE 1950s?
}

\author{
Sarah Zydervelt, Rachel Zajac, Andy Kaladelfos and Nina Westera*
}

Despite widespread reforms to legislation and policy, rape complainants still find cross-examination distressing, demeaning and humiliating. We conducted a systematic and holistic examination of cross-examination strategies to discern: (1) the range of tactics that defence lawyers use to challenge rape complainants' accounts; and (2) whether-and if so, how-the approaches used currently differ from those used prior to the reforms. We compared the strategies and tactics used in cases that were prosecuted in the 1950s to those used in cases from the turn of the twenty-first century. Although contemporary complainants were subjected to lengthier cross-examinations involving a broader range of tactics than their historical counterparts, there was little difference in the breakdown of strategies and tactics across time periods.

Key words: rape, prosecution, cross-examination, courtroom questioning, historical comparison

\section{Introduction}

Victims of rape $^{1}$ describe cross-examination as the most distressing part of their experience within the criminal justice system (Kebbell et al. 2007). Although a plethora of law reforms in common law countries have been implemented since the 1970s with the aim of improving aspects of the criminal justice response for rape complainants, the feeling is that 'nothing has changed' (Lees 1996). That is, victims still report that being cross-examined is a distressing, demeaning and humiliating experience (Kingi and Jordan 2009). In the present study, we explored this issue by looking at the content of cross-examining lawyers' questions to determine the strategies that they use to discredit the evidence of rape complainants. Specifically, we examined whether-and if so, how-the tactics used in cases that were prosecuted in the 1950 s differ from those used in cases from the turn of the twenty-first century.

\footnotetext{
*Nina Westera, Griffith Criminology Institute, Griffith University, 176 Messines Ridge Road, Mt Gravatt, QLD 4122, Australia; n.westera@griffith.edu.au; Sarah Zydervelt and Rachel Zajac, Psychology Department, University of Otago, Otago, New Zealand; Andy Kaladelfos, Griffith Criminology Institute, Griffith University, Mt Gravatt, QLD, Australia

${ }^{1}$ In this article, we use the term 'rape' to describe sexual assaults committed by men against women. We do not use the term in a strict legal sense, as over time its definition changes. For example, one historical definition limited the offence of rape to penile penetration of the vagina. However, legislative reforms in New Zealand in 1985 saw the replacement of the offence 'rape' with the offence 'sexual violation'. This definition broadened the offence so both men and women could be charged with sexual violation if they engaged in any form of penetration of the body of another person using part of their own body or an object, without the consent of that person or without believing on reasonable grounds that the other person consents. We have restricted our discussion to sexual offences committed by men against women because of the unique attributes of this type of crime due to its gendered nature and the absence of legislation that would allow prosecutions to proceed against men who sexually offended against other men.
}

Page 1 of 19

(C) The Author 2016. Published by Oxford University Press on behalf of the Centre for Crime and Justice Studies (ISTD). All rights reserved. For permissions, please e-mail: journals.permissions@oup.com 


\section{Background and law reforms}

In the 1950s, criminal procedure offered little protection for rape complainants (Featherstone and Kaladelfos, in press). No specialist policing services were available for rape victims, and there were no protocols for medical examinations. Complainants were routinely asked humiliating questions about their sexual morals and respectability, including their purported sexual history, sexual reputation, sexual desires and modes of dress. Newspapers regularly reported verbatim testimony from rape trials, often including complainants' names, addresses and even photographs. Rape prosecutions were the lowest of all sexual offences.

From the 1970 s, the combined voices of feminist academics and activists led to widespread and significant changes to both policy and legislation for rape cases in common law jurisdictions (Berger 1977; Estrich 1987; Lees 1996). Common policy reforms included the development of specialist services for rape complainants-multi-agency centres were set up, housing many victim services in one place and providing wrap around services to make the process of reporting easier for complainants. Police, nurses, doctors, lawyers and judges working within the area of sexual assault were also given specialized training on how to respond to complainants. In court, special measures were put in place to reduce the stress associated with giving evidence in courtfor example, allowing complainants to give their evidence from behind screens or via closed-circuit television (see Daly 2011 for a review of policy reforms).

Although the scope and timing of legal reforms varied across jurisdictions, legal reforms commonly targeted four main areas (Horney and Spohn 1991; Lees 1996; Temkin 2000). First, the crime of rape (penile penetration of a woman's vagina) was replaced with a series of gender-neutral offences; under the reforms, the offences included sexual acts other than intercourse, recognized male victims and criminalized sexual offences within marriage. Second, whereas it had previously been necessary in many US jurisdictions for the prosecution to establish that the victim physically resisted the assault, the reforms removed this obligation. Third, reforms removed the requirement for independent evidence to corroborate the complainant's account, or for the judge to warn the jury about the danger of convicting on the complainant's evidence alone. Finally, restrictions were placed on the introduction of evidence about the complainant's previous sexual conduct.

Advocates of these policies and legal reforms believed that improving the treatment of victims would lead to increased reporting of rape while removing the legal barriers to successful prosecution in these cases (Cobb and Schauer 1974). Indeed, the reforms did appear to improve one of these metrics. In a review of rape attrition studies in five countries, ${ }^{2}$ Daly and Bouhours (2010) found that complainants reported sexual assault to police at a higher rate in the period between 1995 and 2005 than in the period between 1970 and 1989. In other respects, however, the reforms appear to have had little impact (Bachman and Paternoster 1993; Cook 2011; Jordan 2011). In fact, Daly and Bouhours (2010) found that the average conviction rate in the five countries over the same time period decreased from 18 per cent of cases reported to police to an average of 12.5 per cent.

What about improvements in rape complainants' experiences of the criminal justice process? Here again, there are some indications that reforms may have been successful

${ }^{2}$ The five countries were Australia, Canada, England and Wales, United States and Scotland. 
(Kebbell et al. 2007; Kingi and Jordan 2009; Stern 2010). In a survey of 19 rape complainants who had given evidence in court, for example, most participants reported that they were generally satisfied with the criminal justice response (Kebbell et al. 2007). Complainants felt that they understood courtroom procedures and reported that they were reasonably able to give accurate evidence (Kebbell et al. 2007).

Concerns are still prevalent, however, about what is often considered the most damaging part of the process-cross-examination (Temkin 2000; Kebbell et al. 2007; McDonald and Tinsley 2011). Complainants in Kebbell and colleagues' study, for example, were dissatisfied with the defence lawyer's performance and felt the defence lawyers were more likely than prosecuting lawyers to accuse them of lying, attack their evidence, put their character in doubt, put words in their mouth, or use trickery or leading questions. It is not uncommon for complainants to report that the suspicion and disbelief that they encounter during cross-examination feels like a repeat of the trauma of being raped (Lees 1996; Konradi 1999; Kingi and Jordan 2009; Wheatcroft et al. 2009) — a phenomenon often referred to as 'secondary victimization' (Williams 1984).

\section{Cross-examination strategies}

The fundamental goal of cross-examination is to discredit both the evidence and the person providing it while eliciting information that is helpful to one's case. Because cross-examination by definition involves testing a witness's credibility and reliability, some of the difficulties that rape complainants experience may be inherent in the process. Indeed, cross-examination is not a pleasant process for any witness, including expert witnesses and police officers (Brereton 1997; Ellison 1998; Brodsky 2004). Nevertheless, in an adversarial trial the defendant is presumed innocent, and defence lawyers have a duty to defend their clients by discrediting the evidence against them, whatever form that evidence takes. Because a complainant's evidence in rape cases is central to establishing the alleged offending, defence lawyers' main-and often onlyavenue of defence is to discredit the complainant's account through cross-examination (Temkin 2000).

But there are various ways of challenging a complainant's evidence. Asking a complainant why two aspects of her account contradict each other, for example, would be considered by many to be a valid tactic. On the other hand, many would consider asking the complainant why she didn't physically resist the defendant to be an unreasonable tactic. Inherent in these latter types of questions are a number of myths about the context, causes and consequences of sexual assault-often referred to as rape myths (Burt 1980; Costin 1985; Lonsway and Fitzgerald 1994).

Rape myths are beliefs about rape that serve to 'deny, downplay or justify sexually aggressive behaviour that men commit against women' (Bohner et al. 1998 translated in Gerger et al. 2007: 423). They can be descriptive, reflecting how people believe instances of sexual assault typically unfold, or they can be prescriptive, reflecting beliefs about how a victim of sexual assault should react (Gerger et al. 2007). Common rape myths include the belief that victims invite sexual assault by the way that they dress, their consumption of alcohol, their sexual history or their association with males with whom they are not in a relationship; the belief that many women make false allegations of rape; the belief that genuine assault would be reported to authorities immediately; and the belief that victims would fight back-and therefore sustain injury or damage to 
clothing_-during an assault (Costin 1985; Estrich 1987; Lonsway and Fitzgerald 1994; Wheatcroft and Walklate 2014).

Many rape myths assume a sexual code to which the majority no longer adheres (Temkin 2000). In contemporary society, women and men commonly interact with people who are not their partners and engage in a number of sexual relationships over the course of a lifetime (Temkin 2000). Furthermore, a victim's relationship with the defendant - or behaviour before, during and after a sexual assault — is not informative about the authenticity of an allegation. The vast majority of rapes are not committed by a stranger but by someone who is an acquaintance with the complainant or has had an intimate relationship with them (Kelly et al. 2005; Johnson 2012). Rapes are not necessarily reported to authorities immediately, and many are never reported (Lees 1996). There are numerous reasons why rape victims might not physically resist their attackers (Lees 1996), and victims do not necessarily sustain physical injuries from their ordeal (Sugar et al. 2004).

Many of the reforms to the definition of rape and the rules of evidence were developed to prevent leveraging of rape myths. For example, in New Zealand-the location of our contemporary sample-there have been major reforms to rape legislation since the 1970s. 'Rape shield' legislation came into force to prevent the defence from using the complainant's sexual history to attack her credibility. The requirement for judges to warn a jury on the danger of convicting without corroborative evidence such as injuries or damaged clothing (Garrow and Turkington 2015) was also abolished. Similar reforms were introduced in other countries (e.g. Australia, England and Wales; Lees 1996; McDonald and Tinsley 2011). As a consequence, we should see fewer tactics that relate to these areas of law reform in the criminal court today, relative to before the reforms were introduced. But is this the case? And, if so, have other tactics taken their place?

Part of the difficulty in answering these questions is that the nature and form of crossexamination in rape cases is not well understood. We attribute this lack of research to two main factors. First, different academic disciplines have approached courtroom cross-examination in different ways. Psychological research, for example, has focused on the format of the questions asked and how this might influence the responses given (e.g. Kebbell et al. 2003; Zajac et al. 2003; Zajac and Cannan 2009). These studies show that defence lawyers primarily use closed and leading questions, which have considerable potential to reduce the accuracy of a complainant's evidence. In contrast, linguistic research has focused on the power dynamics of the courtroom (e.g. Danet 1980; Conley and O'Barr 2005), showing how defence lawyers use a combative style of questioning to construct a case that is favourable to their client, irrespective of the complainant's evidence. Finally, criminological research has tended to emphasize the degree to which stereotypes about rape and rape complainants play out in the courtroom (e.g. Lees 1996; Brereton 1997). These studies have demonstrated that one approach defence lawyers use to discredit the complainant is to incorporate stereotypes about rape into their lines of questioning during cross-examination. Although all of these studies have provided insights into the form of defence lawyers' questions and the nature of some of the tactics used, they do not enable us to understand the variety and breadth of techniques by which defence lawyers attempt to discredit the complainant's evidence.

Second, accessing the materials necessary to systematically examine cross-examination poses considerable difficulty, and for good reason. Rape complainants' evidence is 
treated with sensitivity and rules of evidence mean that the courtroom is often closed to members of the public-preventing researchers from observing cross-examination and making it difficult to access transcripts of evidence. Further, not all jurisdictions produce transcripts of evidence.

In the present study, we investigated the range of approaches used by defence lawyers to challenge the complainant's evidence. We examined both the broad strategies employed (e.g. casting doubt on the complainant's credibility), and the tactics used to execute each of these strategies (e.g. citing an ulterior motive for making a complaint). We were particularly interested in whether-and if so, how-the strategies and tactics used currently differ from those that were used prior to the reforms.

To achieve these aims, we analysed transcripts of courtroom evidence to identify and quantify the strategies and associated tactics that defence lawyers use to cross-examine complainants. We compared the content of defence lawyers' questions to the complainant in cases that were prosecuted in the 1950s to those prosecuted at the turn of the twenty-first century. We specifically sought to examine the following variables as a function of time period:

(1) The number of questions asked during cross-examination, and in particular the number of questions that were clearly strategy based.

(2) The mean number of tactics employed during cross-examination.

(3) The percentage breakdown of broad strategies used during cross-examination.

(4) The frequency and proportional use of specific tactics during cross-examination.

\section{Method}

\section{Court transcripts}

\section{Contemporary transcripts}

An application was made to the Chief District Court Judge of New Zealand for permission to undertake research into the way in which sexual assault complainants are cross-examined in the courtroom. Letters were sent to District Court Judges around New Zealand, requesting transcripts in which adult complainants of sexual assault gave courtroom evidence. All identifying information was removed from the transcripts before this research project began. Transcripts were from cases heard in New Zealand District Courts between 1996 and 2011.

\section{Historical transcripts}

Historical transcripts were obtained from State Records New South Wales, using the archival records of the Court Reporting Branch, Criminal Transcripts. The verbatim court transcripts were from cases heard in the Court of Quarter Sessions, the Central Criminal Court or the Supreme Court dating from 1950 to 1959. The NSW court transcript series are a unique set of records amongst Australian and New Zealand archival holdings; no other jurisdiction has preserved a continuous series of verbatim criminal trial evidence. We examined all 120 volumes of criminal trial transcripts from 1950 to 1959, and identified 462 transcripts of criminal trials and sentencing hearings for sexual crimes and a further 19 transcripts of appeals on sexual crime convictions. 


\section{Case selection}

The present study analysed how adult complainants of sexual assault were cross-examined in the historical and contemporary cases. Due to the unavailability of historical transcripts in New Zealand and that of contemporary Australian transcripts, our study compares historical transcripts from New South Wales, Australia and contemporary transcripts from New Zealand. Both these jurisdictions have a similar social and cultural heritage, as well as statutory and common law requirements, in their criminal justice processes.

Because the legal and social context of sexual assault cases has changed over the four decades between the transcript samples, we matched the historical and contemporary cases to ensure we had offences that were similar in nature. In total, we matched 21 contemporary transcripts with 21 historical transcripts based on the sex of the complainant and defendant, the number of complainants and defendants, and the approximate age of the complainant. All cases in the sample were matched on these criteria. We identified a further two additional criteria matching for the relationship between the complainant and the defendant, and the nature of the sexual offence. All cases matched on one of these additional factors and 16 matched on both of these factors.

Final sample

The final sample comprised 42 transcripts of complainant evidence $(n=21$ historical; $n=21$ contemporary). All complainants were female and aged 16 years or over at the time of the alleged offence, which was the age of consent in both jurisdictions for both time periods. In the cases where the exact age of the complainant was documented ( $n=13$ contemporary cases; $n=12$ historical cases), the age of the contemporary complainants ranged from 16 to 81 years old at the time of the offence $(M=26.69$ years, $S D=18.75$, median $=19$ ) ; the age of the historical complainants ranged from 16 to 72 years old $(M=30.08$ years, $S D=18.92$, median $=20)$. Complainant age, where ascertainable, did not differ as a function of time period, $t(23)=0.45, p=0.66$.

All of the defendants were adult males. The relationship between each complainant and defendant varied. In most cases, the complainant was acquainted with the defendant ( $n=13$ contemporary cases; $n=10$ historical cases). In 10 cases, the defendant was a stranger or had met the complainant on the day of the offence ( $n=4$ contemporary cases; $n=6$ historical cases). In two cases, the defendant was either currently in or had been in an intimate relationship with the defendant $(n=1$ contemporary cases; $n=1$ historical case). In six cases, the defendant was a family member of the complainant ( $n=2$ contemporary cases; $n=4$ historical cases). In the remaining contemporary case there were two defendants, one of whom had been intimately involved with the complainant, whereas the other was an acquaintance.

\section{Analytic approach}

We conducted a thematic analysis to identify the range of cross-examination strategies and tactics identified within the transcripts (Strauss and Corbin 1990), with a view to quantifying the ways in which complainants were cross-examined and comparing these across time period. The development of our coding scheme was also facilitated 
by guidance on discrediting evidence provided in leading advocacy manuals (Salhany 1991; Ross 2007; Willy and Rapley 2013; Hampton and Wild 2000), and from specific cross-examination tactics described in previous archival literature examining sexual assault cases and rape myth research (e.g. Berger 1977; Burt 1980; Lonsway and Fitzgerald 1994; Lees 1996; Brereton 1997).

The thematic analysis began with an initial read of all transcripts by one of the researchers (S.Z.), followed by discussion with the remaining researchers. This process led to the identification of four broad strategies used to discredit complainants and their testimony: credibility challenges, reliability challenges, plausibility challenges and consistency challenges. We conducted a second-level analysis of the data using the same approach but focusing on the specific tactics that defence lawyers commonly used under each strategy. Although these two stages are presented linearly, there was continuous backwards and forwards engagement with the text as themes were developed and refined. Identified strategies and corresponding tactics are presented in Table 1.

Four aspects of the development of our coding scheme deserve special mention. First, we agreed only to code questions that were clearly based on a specific strategy. Questions directing the complainant's attention to an exhibit, for example, were not coded.

Second, because we were interested in the lawyers' tactics, we agreed to code for the intention of the question rather than the complainant's response to it. For example, if a lawyer suggested that the complainant had had a previous sexual relationship with the defendant, this question was coded as a credibility challenge based on previous sexual relationship, even if the complainant stated that the relationship never happened or was not sexual. As a consequence, our data do not reflect how often various themes were present in the facts of the case, but rather how often cross-examining lawyers used these themes as a tactic.

Third, we agreed to code lines of questioning. That is, if several consecutive questions led to a specific challenge, then all of these questions were coded according to the specific challenge ultimately used. Because the lawyer's tactics were not always clear from the outset, this was often achieved by identifying the ultimate question (e.g. "What I'm putting to you is that you've given two different and conflicting accounts of this. Do you agree with me?') and then working backwards to identify where that line of questioning began.

Finally, because lawyers often accused the complainant of inconsistency as a means to explore one of the other strategies, we agreed to code consistency challenges in addition to the relevant strategy. For example, if a cross-examining lawyer said 'You said you were hurt, but the nurse who examined you will testify that you had no bruises on your body,' this question was given both a consistency code and a plausibility code.

Two researchers (S.Z. and N.W.) then independently coded 25 per cent of the transcripts from each time period. Across these transcripts, a Cohen's Kappa coefficient of 0.72 was obtained (see Bakeman and Gottman 1997, for a discussion of why Cohen's Kappa is generally a more conservative measure of inter-rater reliability than percentage agreement). This calculation was performed at the level of the tactic, and took into account both whether the question had an identifiable tactic and which tactic was identified. Disagreements were then resolved by discussion, after which one of the researchers coded all of the remaining transcripts. 
ZYDERVELT ET AL.

TABLE 1 Strategies and tactics identified in the transcripts

\begin{tabular}{|c|c|c|}
\hline Strategy & Tactic & Examples from transcripts \\
\hline \multirow[t]{14}{*}{ Plausibility } & \multirow[t]{2}{*}{ Defendant's good character } & $\begin{array}{l}\text { And there was nothing at all in his conduct to which } \\
\text { you could take exception? (Historical) }\end{array}$ \\
\hline & & [Tactic not present in contemporary transcripts] \\
\hline & \multirow[t]{2}{*}{ Lack of injury or clothing damage } & Were the pants torn? (Historical) \\
\hline & & $\begin{array}{l}\text { And somehow that those [broomstick] were } \\
\text { negotiated safely into your vagina, because you } \\
\text { weren't bleeding were you? (Contemporary) }\end{array}$ \\
\hline & \multirow{2}{*}{$\begin{array}{l}\text { Complainant's behaviour immediately } \\
\text { before and after offence }\end{array}$} & You walked back side by side? (Historical) \\
\hline & & You willingly took your clothes off? (Contemporary) \\
\hline & \multirow[t]{2}{*}{ Lack of resistance } & $\begin{array}{l}\text { Did you scratch the accused? [...] Did } \\
\text { you bite the accused? (Historical) }\end{array}$ \\
\hline & & $\begin{array}{l}\text { Whilst the first part of the incident was taking } \\
\text { place and he was kissing your body and } \\
\text { touching you, you actually didn't say anything } \\
\text { at that stage did you? (Contemporary) }\end{array}$ \\
\hline & \multirow[t]{2}{*}{ Delayed report } & $\begin{array}{l}\text { You had the opportunity to tell her what } \\
\text { happened when these two men went into the } \\
\text { hamburger shop didn't you? (Historical) }\end{array}$ \\
\hline & & $\begin{array}{l}\text { So you didn't tell }[\mathrm{X}] \text { who had been } \\
\text { your friend for eight months what had } \\
\text { happened to you? (Contemporary) }\end{array}$ \\
\hline & \multirow[t]{2}{*}{ Continued relationship } & $\begin{array}{l}\text { Is this the position, at the time in [year] when you } \\
\text { loathed and hated your father for these beastly } \\
\text { things he was doing to you, you addressed a note } \\
\text { to him, 'Dear Daddy', and ended it 'tons of love, } \\
\text { [name]', three kisses, three hugs? (Historical) }\end{array}$ \\
\hline & & $\begin{array}{l}\text { It's just instead of getting straight out of the car, you } \\
\text { agreed to meet with this person who had supposedly } \\
\text { raped and against your will sodomized you a } \\
\text { couple of days later didn't you? (Contemporary) }\end{array}$ \\
\hline & \multirow[t]{2}{*}{ Other } & That must have made you very suspicious? (Historical) \\
\hline & & $\begin{array}{l}\text { I suggest he couldn't have done both } \\
\text { those things at the same time. What do } \\
\text { you say about that? (Contemporary) }\end{array}$ \\
\hline \multirow[t]{4}{*}{ Credibility } & \multirow[t]{2}{*}{ Prior relationship with the defendant } & $\begin{array}{l}\text { You went with him one night to } \\
\text { [town] in his car? (Historical) }\end{array}$ \\
\hline & & $\begin{array}{l}\text { And you came back voluntarily from [another state] } \\
\text { to live with [the defendant]? (Contemporary) }\end{array}$ \\
\hline & \multirow[t]{2}{*}{ Sexual history } & $\begin{array}{l}\text { Had [complainant's previous employer] complained } \\
\text { about your behaviour with young men? (Historical) }\end{array}$ \\
\hline & & $\begin{array}{l}\text { And [another person] I think you said, had } \\
\text { been your - not your boyfriend, but your } \\
\text { friend, more of a special friend for about two } \\
\text { weeks. [...] You'd been sleeping with him } \\
\text { for about two weeks? (Contemporary) }\end{array}$ \\
\hline
\end{tabular}


TABle 1 Continued

\begin{tabular}{|c|c|c|}
\hline Strategy & Tactic & Examples from transcripts \\
\hline & \multirow[t]{2}{*}{ Personal traits } & You have always been keen on acting? (Historical) \\
\hline & & $\begin{array}{l}\text { You started a new job at the beginning } \\
\text { of the week and didn't go back after your } \\
\text { first day there? (Contemporary) }\end{array}$ \\
\hline & \multirow[t]{2}{*}{ Previous sexual assault complaint } & $\begin{array}{l}\text { Did you allege to the police in [city] that a man had } \\
\text { assaulted you with intent to rape you? (Historical) }\end{array}$ \\
\hline & & $\begin{array}{l}\text { Because on [date] you made a very personal } \\
\text { revelation to [the defendant] didn't you? } \\
\text { [...] About the fact that you had been abused } \\
\text { violated as a child. (Contemporary) }\end{array}$ \\
\hline & \multirow[t]{2}{*}{ Ulterior motive } & $\begin{array}{l}\text { Did you tell Mrs X this that you could sue [the } \\
\text { defendant] for thousands of pounds? (Historical) }\end{array}$ \\
\hline & & $\begin{array}{l}\text { You wanted to ruin [the defendant's] } \\
\text { name didn't you? (Contemporary) }\end{array}$ \\
\hline & \multirow[t]{2}{*}{ Reason not given } & This whole story of the tablet is a lie isn't it? (Historical) \\
\hline & & $\begin{array}{l}\text { Well I suggest to you that the tale that you } \\
\text { kneed him in the balls was pure invention } \\
\text { on your part. (Contemporary) }\end{array}$ \\
\hline \multirow[t]{8}{*}{ Reliability } & \multirow[t]{2}{*}{ Alcohol/drug intoxication } & $\begin{array}{l}\text { I suggest that you were at the dance very } \\
\text { much under the influence? (Historical) }\end{array}$ \\
\hline & & $\begin{array}{l}\text { Now [complainant] you, on that night you'd had } \\
\text { quite a bit to drink hadn't you? (Contemporary) }\end{array}$ \\
\hline & \multirow[t]{2}{*}{ Barriers to perception } & $\begin{array}{l}\text { Was the reason you were unable to see because } \\
\text { there was not enough light? (Historical) }\end{array}$ \\
\hline & & This all happened very fast didn't it? (Contemporary) \\
\hline & \multirow[t]{2}{*}{ Memory fallibility } & Is your memory faulty? (Historical) \\
\hline & & $\begin{array}{l}\text { Can I suggest to you that you're actually having } \\
\text { trouble remembering and that you're now trying } \\
\text { to reconstruct these events? (Contemporary) }\end{array}$ \\
\hline & \multirow[t]{2}{*}{ Reason not given/Other } & $\begin{array}{l}\text { You are not too sure if you had any } \\
\text { tablets at all are you? (Historical) }\end{array}$ \\
\hline & & $\begin{array}{l}\text { But wasn't everything still a little bit dreamy or } \\
\text { were you still feeling a bit asleep when you woke } \\
\text { up and ran out, out the door? (Contemporary) }\end{array}$ \\
\hline \multirow[t]{4}{*}{ Consistency } & \multirow[t]{2}{*}{ With complainant's own account } & $\begin{array}{l}\text { What I'm putting to you is that you've given } \\
\text { two different and conflicting accounts of } \\
\text { this. Do you agree with me? (Historical) }\end{array}$ \\
\hline & & $\begin{array}{l}\text { You told police a different version about how you } \\
\text { came onto your hands and knees? (Contemporary) }\end{array}$ \\
\hline & \multirow[t]{2}{*}{ With defendant's account } & $\begin{array}{l}\text { I put it to you - and you can say what you } \\
\text { wish to it - that [the defendant] kissed you } \\
\text { and you did not object to it? (History) }\end{array}$ \\
\hline & & $\begin{array}{l}\text { Do you remember [the defendant] saying why } \\
\text { don't we go home, you go in the shower and clean } \\
\text { yourself and we'll go for a drive? (Contemporary) }\end{array}$ \\
\hline
\end{tabular}




\begin{tabular}{|c|c|c|}
\hline Strategy & Tactic & Examples from transcripts \\
\hline & \multirow[t]{2}{*}{ With another witness's account } & $\begin{array}{l}\text { And you heard her [the bush nurse] say } \\
\text { [in her evidence] that there was a mark } \\
\text { but it wasn't a bruise? (Historical) }\end{array}$ \\
\hline & & $\begin{array}{l}\text { But [witness] told us that after she came back she } \\
\text { saw you walking away and not crawling or hiding } \\
\text { and she walked after you? (Contemporary) }\end{array}$ \\
\hline & \multirow[t]{2}{*}{ With physical evidence } & $\begin{array}{l}\text { Exactly the same, is it [the watch]? Will you } \\
\text { agree that those figures } 12,3,6 \text {, and } 9 \text { are } \\
\text { not illuminated at all by being traced out, } \\
\text { but they are only dots? (Historical) }\end{array}$ \\
\hline & & $\begin{array}{l}\text { You are saying there was no winder or no handle } \\
\text { [inside the car door]? (Contemporary) }\end{array}$ \\
\hline
\end{tabular}

\section{Results}

\section{Overall characteristics of cross-examination}

Sexual assault complainants in contemporary cases were, on average, asked 27 per cent more cross-examination questions, $t(40)=-1.12, p=0.28$ and 34 per cent more clear strategy-based questions, $t(40)=-1.25, p=0.22$, than complainants in historical cases, although considerable variation in cross-examination lengths and a relatively small sample size meant that these differences did not reach conventional levels of statistical significance. Lawyers conducting contemporary cross-examinations used a significantly larger number of specific tactics than those conducting historical cross-examinations, $t(40)=-2.26$, $p=0.03$. The number of strategy-based questions as a proportion of the total number of cross-examination questions remained similar across time period, $t(40)=-0.92, p=0.37$ (see Table 2). The upshot of these findings is that contemporary cross-examinations are more wide ranging and perhaps somewhat longer than those conducted historically.

\section{Broad strategies during cross-examination}

Defence lawyers from both time periods used a similar broad approach to cross-examining sexual assault complainants-adopting an assortment of strategies that targeted the complainant's reliability, consistency with other evidence, credibility and the plausibility of the allegation.

Proportions of strategy-based questions in the four broad categories-plausibility, credibility, reliability and consistency-did not differ significantly across time period, $t(40)=-0.64, p=0.56, t(40)=-0.84, p=0.41, t(40)=-1.49, p=0.14$, and $t(40)=-1.12$, $p=0.27$, respectively. That is, regardless of when the case was heard, lawyers spent the most time challenging plausibility, followed by consistency, credibility and then reliability (see Table 3).

\section{Specific tactics during cross-examination}

What tactics did defence lawyers use to execute these strategies? Table 4 shows the tactics that defence lawyers employed within each of the four broad strategies. For 
TABle 2 Overall means

\begin{tabular}{lll}
\hline & Historical $(n=21)$ & Contemporary $(n=21)$ \\
\hline Total cross-examination questions & 222 & 281 \\
Strategy-based questions & 163 & 218 \\
Per cent strategy-based questions & $72 \%$ & $76 \%$ \\
Number of tactics used & 7.81 & $9.57^{*}$ \\
\hline
\end{tabular}

$* p<0.05$.

TABLE 3 Broad strategies used during cross-examination, shown as a percentage of strategy-based questions

\begin{tabular}{lll}
\hline & Historical, \% $(n=21)$ & Contemporary, \% $(n=21)$ \\
\hline Plausibility & 49 & 45 \\
Credibility & 18 & 23 \\
Reliability & 5 & 12 \\
Consistency & 27 & 20 \\
\hline
\end{tabular}

Because consistency challenges were often used in conjunction with other types of challenge, all questions assigned a consistency code could also receive one of the other codes. In this table, however, consistency values reflect questions in which a consistency challenge was the only strategy employed.

each tactic, we asked two questions. First, in what percentage of cases was the tactic employed? These data are displayed in the Frequency columns of Table 4. Second, when the tactic was employed, what proportion of the strategy-based questions did defence lawyers devote to it? These data are displayed in the Proportion columns of Table 4.

\section{Plausibility tactics}

The most common method of challenging the plausibility of the complainant's allegation was citing the complainant's behaviour immediately before the offence (e.g. willingly accompanying the defendant to a secluded place) or immediately afterwards (e.g. returning to a party with the defendant). This approach was used in more of the cases-and more often in those cases-than any of the other plausibility challenges, regardless of time period.

Q. And [complainant's female friend] did in fact suggest you go home with her didn't she? ${ }^{3}$

A. She said 'Are you coming home with me?' and I said 'No'.

Q. At the [hotel] is this the position, that you preferred the company of the accused to [complainant's female friend]?

A. Well, seeing that I was asked if I would like a lift home, I accepted. (Historical)

Q. Because of what you say happened to you, did you think, at any stage of simply running away from the scene?

A. Yeah I was thinking that but everywhere was pitch black. (Contemporary)

\footnotetext{
${ }^{3}$ Quotes include all speech errors and any typographical errors made during transcription, but they have been edited to remove identifiable information.
} 
ZYDERVELT ET AL.

TABLE 4 Strategies and tactics employed in the cases

\begin{tabular}{|c|c|c|c|c|c|}
\hline \multirow[t]{2}{*}{ Strategy } & \multirow[t]{2}{*}{ Tactic } & \multicolumn{2}{|c|}{ Frequency, \% } & \multicolumn{2}{|c|}{ Proportion $(n)$} \\
\hline & & Historical & Contemporary & Historical & Contemporary \\
\hline \multirow[t]{7}{*}{ Plausibility } & Defendant's good character & 29 & $0 * *$ & $0.05(6)$ & N/A $(0)$ \\
\hline & Lack of injury or clothing damage & 43 & 33 & $0.13(9)$ & $0.07(7)$ \\
\hline & $\begin{array}{l}\text { Complainant's behaviour immediately } \\
\text { before and after offence }\end{array}$ & 86 & 90 & $0.25(18)$ & $0.23(19)$ \\
\hline & Lack of resistance & 43 & 24 & $0.11(9)$ & $0.04(5)$ \\
\hline & Delayed report & 43 & $71^{\mathrm{m}}$ & $0.05(9)$ & $0.09(15)$ \\
\hline & Continued relationship & 19 & 33 & $0.07(4)$ & $0.07(7)$ \\
\hline & Other & 90 & 90 & $0.15(19)$ & $0.14(19)$ \\
\hline \multirow[t]{6}{*}{ Credibility } & $\begin{array}{l}\text { Prior relationship with } \\
\text { the defendant }\end{array}$ & 33 & 48 & $0.08(7)$ & $0.10(10)$ \\
\hline & Sexual history & 38 & 43 & $0.12(8)$ & $0.04(9)$ \\
\hline & Personal traits & 57 & 62 & $0.11(12)$ & $0.06(13)$ \\
\hline & Previous sexual assault complaint & 5 & 10 & $0.14(1)$ & $0.04(2)$ \\
\hline & Ulterior motive & 57 & 76 & $0.06(12)$ & $0.13(16)$ \\
\hline & Reason not given & 19 & $71 * *$ & $0.03(4)$ & $0.03(15)$ \\
\hline \multirow[t]{4}{*}{ Reliability } & Alcohol/drug intoxication & 33 & 57 & $0.08(7)$ & $0.11(12)$ \\
\hline & Barriers to perception & 10 & 24 & $0.03(2)$ & $0.04(5)$ \\
\hline & Memory fallibility & 29 & $57^{\mathrm{m}}$ & $0.03(6)$ & $0.06(12)$ \\
\hline & Reason not given/Other & 24 & 38 & $0.07(5)$ & $0.03(8)$ \\
\hline \multirow{4}{*}{ Consistency } & With complainant's own account & 90 & 71 & $0.28(19)$ & $0.19(15)$ \\
\hline & With defendant's account & 71 & 81 & $0.11(15)$ & $0.16(17)$ \\
\hline & With another witness's account & 5 & $48 * *$ & $0.09(1)$ & $0.08(10)$ \\
\hline & With physical evidence & 5 & 19 & $0.17(1)$ & $0.04(4)$ \\
\hline
\end{tabular}

Data in the Frequency columns reflect the percentage of cases in which the tactic was used. Data in the Proportion columns reflect the proportion of strategy-based questions devoted to the tactic, in cases where it was used. 'Defendant's good character', for example, was raised in 29 per cent of historical cases and 0 per cent of contemporary cases. In the historical cases in which this tactic was used, it accounted for 5 per cent (a proportion of 0.05 ) of the strategy-based questions.

${ }^{* *} p<0.01 ;{ }^{\mathrm{m}} p<0.10$.

Other plausibility tactics showed considerable differences across time period. Promoting the defendant's good character, for example, was a relatively common tactic in the historical cases, but never used contemporarily.

Q. I put it to you that [accused] himself at the [hotel] was decent in all respects to you?

A. Yes.

Q. Good mannered?

A. Yes.

Q. Courteous?

A. Yes. (Historical)

Similarly, lack of injury or clothing damage and lack of resistance were less likely to be cited in contemporary cases, relative to historical ones-and used proportionally less when they were deployed.

Q. Why didn't you kick him?

A. I was frightened.

Q. Frightened of what?

A. Well I did not want to get hurt more than I was. (Lack of resistance, Historical) 
Q. I think when describing the incident at the Lower Court, do you agree that you said, 'he ripped them off'?

A. Yes.

Q. You used those words didn't you?

A. Yes.

Q. Are the pants torn?

A. I don't know. I have not had a good look at them. I have only seen them from a distance. (Lack of injury or clothing damage, Historical)

As these tactics decreased, the use of others increased. In particular, relative to historical cases, defence lawyers in contemporary cases were more likely to question complainants about delayed reporting and maintaining a relationship with the accused following the offence.

Q. Was it your mother's direction that you go to the police?

A. She said that I should go and make a complaint because it was the right thing to do.

Q. Your response was that you did want to did you?

A. No I didn't want to go through all this court thing, I'd seen what this kind of thing had done to my sister and I didn't want to go through it. (Delayed report, Contemporary)

Q. And you carried on working for [defendant] after each of these three incidents didn't you?

A. Yes. (Continued relationship, Contemporary)

\section{Credibility tactics}

Across both time periods, the most common credibility tactics targeted the complainant's personal traits or potential ulterior motives for making the allegation.

Q: Apart from posing as a model, was it your usual custom to dress in a way which is as adult as this? In other words to make you look as old as this photograph makes you look? (Personal traits, Historical)

Q. You have a tendency to over-dramatize don't you? (Personal traits, Contemporary)

Q. The money wasn't paid and when you learnt that the complaint was made? (Ulterior motive, Contemporary)

Q. You became frightened of pregnancy and it was only for that reason that you made a complaint about it? (Ulterior motive, Historical)

The next most common tactics in both periods were citing the complainant's prior relationship with the defendant and citing her sexual history with people other than the defendant.

Q. I do not mean any offence, [Complainant], but you had been kissed by young men prior to this occasion? (Sexual history, Historical)

Q. You gave him your number?

A. Yes.

Q. Do you allow that to happen with every [New Zealander] that strikes you up for conversation? (Prior relationship with the defendant, Contemporary) 
Although restrictions have been placed on the use of both of these tactics since the law reforms, they were actually more likely to appear in contemporary transcripts than in historical cases. In fact, all of the credibility tactics were used in more contemporary cases than historical cases.

Although each of the credibility tactics was used in more contemporary cases than historical cases, when they were used they accounted for a smaller proportion of the strategy-based questions. This difference was particularly notable when defence lawyers cited the complainant's sexual history, personal traits and previous complaints of sexual assault.

\section{Reliability tactics}

All tactics aimed at challenging the complainant's reliability-intoxication, barriers to perception and memory fallibility-were more likely to arise in contemporary cases than in historic cases. Across both time periods, defence lawyers were most likely to cite alcohol and/or drug intoxication and memory fallibility as reasons to doubt the reliability of the complainant's account.

Q. But it took you a while to realize what was happening because you were drunk and asleep didn't it? (Alcohol/drug intoxication, Contemporary)

Q. How much drink had you actually had that afternoon and night? (Alcohol/drug intoxication, Historical)

Q. But it's hard to remember now what really happened on that day isn't it? (Memory fallibility, Contemporary)

Proportional use of each reliability tactic was similar across time periods, with small increases across time for intoxication and memory fallibility challenges.

\section{Consistency tactics}

Across both time periods, defence lawyers frequently highlighted ways in which the complainant's courtroom account of the offence was inconsistent with other evidence.

Q. Did he put his hand around your neck?

A. No.

[...]

Q. I put it to you that you said before the magistrate that he put one hand around your neck? (Inconsistency with complainant's own account, Historical)

Q. Because [Defendant] has described to the police, quite sustained vaginal sexual activity, you don't have any recollection of that during that possible hour period?

A. No. (Inconsistency with defendant's account Contemporary)

The specific evidence used as a comparison, however, differed somewhat across time period. Inconsistency within the complainant's account, for example, was cited less often in contemporary cases than in historical cases, whereas citing the complainant's inconsistency with other accounts - the defendant's account, another witness's account, or physical evidence-showed the opposite trend. In cases where each of these tactics was used, in contemporary cases proportionally fewer questions were devoted to 
inconsistencies with the physical evidence or within the complainant's account when compared to historical cases. Proportionally more questions were devoted to consistency with the defendant's account, while the proportion of questions devoted to inconsistency with the other witnesses showed little change.

\section{Discussion}

Our overarching finding is that, relative to 50 years ago, defence lawyers who question rape complainants are merely pursuing the same goals in slightly different ways. In essence, little has changed. Even after significant reforms to policy and law, complainants still find cross-examination to be distressing and demeaning (Kebbell et al. 2007), and our data show that this sentiment is understandable given the tactics employed.

Tactics leveraging rape myths were common. Cross-examining lawyers frequently invoked stereotypes about complainants' behaviour - that is, about how complainants typically behave and how they ought to have behaved, with the benefit of hindsight. In over 85 per cent of cases, for example, the complainant's behaviour leading up to and after the alleged offence was used to infer that she had consented to the sexual acts (e.g. that the complainant went somewhere voluntarily with the defendant prior to the offence). In around 60 per cent of cases, defence lawyers alleged that the complainant's personal traits-for example, her work as an actor or prostitute, or her parenting failures-made her less credible.

Furthermore, we saw very little meaningful reduction in these tactics over time. In fact, only four of the tactics that we identified were less likely to be employed in contemporary cases than in historical cases, and only one of these differences reached conventional levels of statistical significance. Remaining tactics were either employed at similar rates across time periods or used more often in contemporary cases than historical cases. Overall, lawyers in contemporary cases asked complainants more questions and employed a wider variety of tactics.

Although the design of our study does not enable us to determine causal relations, there are two primary-and non-mutually exclusive-ways of accounting for the differences that we observed. The first is law reforms; two tactics that were less often used in the contemporary period-complainant resistance during the offence and injury or damage to clothing-related to areas where law reform about corroboration has restricted the need to introduce such evidence in rape cases. However, even these differences were not of a sufficient magnitude to reach statistical significance. Furtherdespite this being a significant area of law reform-43 per cent of lawyers in the contemporary cases still asked questions about the complainant's prior sexual history (both with and without the defendant), although they spent a lower proportion of their time doing so.

The other possibility is that changes in social context over time could have influenced courtroom proceedings. That is, differences in the types of tactics that defence lawyers use could reflect changes in the types of cases that are (1) reported and (2) contested at trial. In the past 15 years, for example, a higher proportion of rapes reported to the police were committed by someone known to the complainant (as opposed to a stranger) than they were historically (Daly and Bouhours 2010); the contemporary cases could therefore have been more varied in character than the historical cases. Although we matched our cases on their broad characteristics in order to control for this fact, there 
were other potential confounds that we could not control for. For instance, although we observed that lawyers in contemporary cases were more likely than lawyers in historical cases to challenge complainants about delayed reporting and memory fallibility, these findings may simply reflect more cases involving delayed reporting now going to court. Differences in defence lawyers' tactics during cross-examination might also be due to changes in norms relating to social behaviour. For example, the heightened status of men in society in the historical period might have meant that raising a defendant's good character - the only tactic for which we observed a significant decrease in frequency across the two time periods-was more profitable for the defence case than it would be today.

\section{Implications}

Overall, our findings support the views of some researchers that legal reforms, which simply restrict questioning, are unlikely to overcome the problems with cross-examination (Ellison 1998; McDonald and Tinsley 2011). The root of the problems with cross-examination likely lies in the combative nature of proceedings-a fundamental feature of the adversarial trial. Simply put, the defence lawyer's job is to do whatever is necessary, within legal limits, to create reasonable doubt. If one avenue of cross-examination is not available, they will likely try another. Because the complainant's account is the central-and sometimes only-evidence in rape cases, that evidence constitutes the main target for attack.

Are there other ways to reduce the use-or impact—of rape myths and other stereotypes during cross-examination? Given the similarity of the tactics used across cases and time periods, it could be possible to anticipate the issues that a complainant will be cross-examined on, and therefore take more of a preemptive approach. Expert evidence or judicial instruction could be used, for example, to explain aspects of the complainant's behaviour that might be seen by fact-finders as counter-intuitive (Ellison 2007). Investigators and prosecutors could also address these issues directly with complainants early on - at the time the allegation is made or when preparing complainants for court (Kebbell and Westera 2011), or even during evidence-in-chief (Ellison 2007). More work in this area could inform interview protocol and planning strategies for investigators and prosecutors.

Ultimately, many researchers argue that criminal justice system reforms will have little impact on courtroom practices until there are changes in societal attitudes towards rape (e.g. Temkin and Krahé 2008; McDonald and Tinsley 2011; Leahy 2014). Judges and juries are not imbued with a special ability to determine the truth; instead, they rely on their understanding of human nature and common sense (Salhany 1991). Defence lawyers are likely to be using tactics that rely on stereotypes about rape because they believe that fact-finders will be swayed by these stereotypes-that is, they use these tactics because they perceive them to be successful (Temkin 2000).

Indeed, empirical evidence supports the idea that many jurors believe these misconceptions about rape (Amnesty International 2005). Furthermore, mock jurors who subscribe to these beliefs allocate more blame to victims, allocate less blame to perpetrators and are less likely to return a guilty verdict in a sexual assault case (Gray 2006; Ellison and Munro 2010; Grubb and Turner 2012). Perhaps, then, cross-examination will not change until social beliefs about rape do. After all, lawyers have a duty to defend their 
clients. To the extent that putting these myths in front of the jury has a good chance of creating reasonable doubt, it is likely that lawyers will continue to use them.

\section{Concluding comments}

Defence lawyers employ a predictable series of tactics when cross-examining complainants in rape cases. By systematically identifying and quantifying these tactics, we have been able to ascertain that approaches to cross-examination are very similar nowadays to those employed 50 years ago. This is the first study to comprehensively examine the way in which rape complainants are cross-examined, however. More research is required to assist criminal justice professionals and policy makers to make informed decisions about how best to address this issue.

\section{Funding}

This work was supported by the Australian Research Council [DP150101798; FL130100050]; and the Marsden Fund Council (from Government funding administered by the Royal Society of New Zealand) [UOO1011].

\section{Acknowledgements}

The authors gratefully acknowledge the contributions of Alana Piper, Mark Finnane, Robyn Blewer, Lisa Durnian and Nathan Ryan.

\section{REFERENCES}

Amnesty International. (2005), 'Sexual Assault Research Report', available online at www. amnesty.org.uk.

Bachman, R. and Paternoster, R. (1993), 'A Contemporary Look at the Effects of Rape Law Reform: How Far Have We Really Come?', Journal of Criminal Law and Criminology, 83: 554-74.

Bakeman, R. and Gottman, J. M. (1997), Observing Interaction: An Introduction to Sequential Analysis, 2nd edn. Cambridge University Press.

Berger, V. (1977), 'Man's Trial, Woman's Tribulation: Rape Cases in the Court Room', Colombian Law Review, 77: 1-103.

Bohner, G., Reinhard, M. A., Rutz, S., Sturm, S., Kerschbaum, B. and Effler, D. (1998), 'Rape Myths as Neutralizing Cognitions: Evidence for a Causal Impact of AntiVictim Attitudes on Men's Self-Reported Likelihood of Raping', European Journal of Social Psychology, 28: 257-68.

Brereton, D. (1997), 'How Different Are Rape Trials? A Comparison of the CrossExamination of Complainants in Rape and Assault Trials', British Journal of Criminology, 37: 242-61.

Brodsky, S. L. (2004), Coping with Cross-Examination and Other Pathways to Effective Testimony. American Psychological Association.

Burt, M. R. (1980), 'Cultural Myths and Supports for Rape', Journal of Personality and Social Psychology, 38: 217-30. 
Cobb, K. A. and Schauer, N. R. (1974), 'Michigan's Criminal Sexual Assault Law', University of Michigan Journal of Law Reform, 8: 184-217.

Conley, J. M. and O'BArr, W. M. (2005), Just Words: Law, Language, and Power. University Of Chicago Press.

Cook, K. (2011), 'Rape Investigation and Prosecution: Stuck in the Mud?', Journal of Sexual Aggression, 17: 250-62.

Costin, F. (1985), 'Beliefs about Rape and Women's Social Roles', Archives of Sexual Behavior, 14: 319-25.

Daly, K. (2011), Conventional and Innovative Justice Responses to Sexual Violence. Australian Centre for the Study of Sexual Assault, Australian Institute of Family Studies.

Daly, K. and Bouhours, B. (2010), 'Rape and Attrition in the Legal Process: A Comparative Analysis of Five Countries', Crime and Justice: An Annual Review of Research, 39: 565-650.

Danet, B. (1980), 'Language in the Legal Process', Law and Society Review, 14: 445-564.

Ellison, L. (1998), 'Cross-Examination in Rape Trials', Criminal Law Review, 605-15.

—_. (2007), 'Promoting Effective Case-Building in Rape Cases: A Comparative Perspective', Criminal Law Review, 691-708.

Ellison, L. and Munro, V. (2010), 'Getting to (Not) Guilty: Examining Jurors' Deliberative Processes in, and Beyond the Context of a Mock Rape Trial', Legal Studies, 30: 74-97.

Estrich, S. (1987), Real Rape. Harvard University Press.

Featherstone, L. and Kaladelfos, A. (in press), Sex Crimes in the Fifties. Melbourne University Publishing.

Garrow, J. M. and Turkington, G. L. (2015), 'Criminal Law in New Zealand', available online at http://www.lexisnexis.com.ezproxy.otago.ac.nz/nz/legal/results/enhPubTreeViewDoc. do?nodeId=TAAB\&backKey=20_T23390120044\&refPt=\&pubTreeWidth=347

Gerger, H., Kley, H., Bohner G. and Seibler, F. (2007), 'The Acceptance of Modern Myths about Sexual Aggression Scale: Development and Validation in German and English', Aggressive Behavior, 33: 442-40.

Gray, J. M. (2006), 'Rape Myth Beliefs and Prejudiced Instructions: Effects on Decisions of Guilt in a Case of Date Rape', Legal and Criminological Psychology, 11: 75-80.

Grubb, A. and Turner, E. (2012), 'Attribution of Blame in Rape Cases: A Review of the Impact of Rape Myth Acceptance, Gender Role Conformity and Substance Use on Victim Blaming', Aggression and Violent Behavior, 17: 443-52.

Hampton, N. and Wild, J. (2000), 'Cross-Examination' in J. B. Robertson, A. Beck and S. Mount, eds, Introduction to Advocacy, 2nd edn, 246-79. New Zealand Law Society.

Horney, J. and Spohn, C. (1991), 'Rape Law Reform and Instrumental Change in Six Urban Jurisdictions', Law and Society Review, 25: 117-53.

Johnson, D., Peterson, J., Sommers, I. and Baskin, D. (2012), 'Use of Forensic Science in Investigating Crimes of Sexual Violence: Constrasting Its Theoretical Potential with Empirical Realities', Violence Against Women, 18: 193-222.

Jordan, J. (2011), 'Here We Go Round the Review-Go-Round: Rape Investigation and Prosecution-Are Things Getting Worse Not Better?', Journal of Sexual Aggression, 17: 234-49.

Kebbell, M. R., Deprez, S. and Wagstaff, G. F. (2003), 'The Direct and Cross-Examination of Complainants and Defendants in Rape Trials: A Quantitative Analysis of Question Type', Psychology, Crime and Law, 9: 49-59.

Kebbell, M. R., O’Kelly, C. M. E. and Gilchrist, E. L. (2007), 'Rape Victims' Experiences of Giving Evidence in English Courts: A Survey', Psychiatry, Psychology and Law, 14: 111-9. 
Kebbell, M. R. and Westera, N. J. (2011), 'Promoting Pre-Recorded Complainant Evidence in Rape Trials: Psychological and Practice Perspectives', Criminal Law Journal, 35: 376-85.

Kelly, L., Lovett, J. and Regan, L. (2005), A Gap or a Chasm? Attrition in Reported Rape Cases. Home Office Research Study 293. Home Office.

Kingi, V. and Jordan, J. (2009), Responding To Sexual Violence: Pathways To Recovery. Ministry of Women's Affairs.

Konradi, A. (1999), “I Don't Have to be Afraid of You”: Rape Survivors' Emotion Management in Court', Symbolic Interaction, 22: 45-77.

LeAhy, S. (2014), 'Bad Laws or Bad Attitudes? Assessing the Impact of Societal Attitudes Upon the Conviction Rate for Rape in Ireland', Irish Journal of Applied Social Studies, 14: $18-29$.

Lees, S. (1996), Carnal Knowledge: Rape on Trial. Hamish Hamilton.

Lonsway, K. A. and Fitzgerald, L. F. (1994), 'Rape Myths in Review', Psychology of Women Quarterly, 18: 133-64.

McDonald, E. and Tinsley, Y. (2011), From "Real Rape" to Real Justice: Prosecuting Rape in New Zealand. Victoria University Press.

Ross, D. (2007), Advocacy, 2nd edn. Cambridge University Press.

Salhany, R. E. (1991), Cross-Examination: The Art of the Advocate, rev. ed. Butterworths Canada Ltd.

Stern, V. (2010), The Stern Review. Home Office.

Strauss, A. and Corbin, J. M. (1990), Basics of Qualitative Research: Grounded Theory Procedures and Techniques. Sage Publications, Inc.

Sugar, N., Fine, D. and Eckert, L. (2004), 'Physical Injury after Sexual Assault: Findings of a Large Case Series', American Journal of Obstetrics and Gynecology, 190: 71-6.

Temkin, J. (2000), 'Prosecuting and Defending Rape: Perspectives from the Bar', Journal of Law and Society, 27: 219-48.

Temkin, J. and Krahé, B. (2008), Sexual Assault and the Justice Gap: A Question of Attitude. Hart Publishing.

Wheatcroft, J. M., Wagstaff, G. F. and Moran, A. (2009), 'Revictimizing the Victim? How Rape Victims Experience the UK Legal System', Victims and Offenders, 4: 265-84.

Wheatcroft, J. M. and Walklate, S. (2014), 'Thinking Differently about 'False Allegations' in Cases of Rape: The Search for Truth', International Journal of Criminology and Sociology, 3: 239-48.

Williams, J. E. (1984), 'Secondary Victimization: Confronting Public Attitudes about Rape', Victimology, 9: 66-81.

Willy, A. A. P. and Rapley, J. R. (2013), Advocacy. Brookers.

Zajac, R. and Cannan, P. (2009), 'Cross-Examination of Sexual Assault Complainants: A Developmental Comparison', Psychiatry, Psychology and Law, 16: 36-54.

Zajac, R., Gross, J. and Hayne H. (2003), 'Asked and Answered: Questioning Children in the Courtroom, Psychiatry, Psychology and Law, 10: 199-209. 